\title{
UPAYA MANAJERIAL PENGEMBANGAN KURIKULUM PROGRAM UNGGULAN DI MADRASAH ALIYAH
}

\author{
Sudarsono \\ (KEMENAG Kabupaten Trenggalek)
}

\begin{abstract}
Abstrak:
Peningkatan mutu pendidikan melalui program unggulan yang diselenggarakan di Madrasah Aliyah turut serta meningkatkan kualitas output pendidikan nasional untuk merespon krisis dalam dimensi kualitas sumber daya manusia maupun krisis dalam bidang identitas dan moralitas manusia Indonesia. Tulisan ini berupaya untuk menyampaikan pandangan tentang upaya manajerial pengembangan kurikulum untuk programprogram unggulan dalam konteks Madrasah Aliyah. Manajemen pengembangan kurikulum program unggulan meliputi perencanaan, pelaksanaan dan evaluasi kurikulum. Perencanaan kurikulum yang dilakukan dalam mencapai tujuan kurikulum adalah kurikulum yang digunakan adalah kurikulum "SNP Plus X Adaptif Cambridge", sehingga siswanya dapat mengikuti ujian Cambridge, sukses ujian nasional dan sukses OSN (olimpiade sains nasional). Dalam pelaksanaan kurikulum mengacu pada silabus dan RPP yang telah dirancang awal ajaran melalui workshop. Evaluasi kurikulum program unggulan dilaksanakan dalam bentuk evaluasi formatif dan evaluasi sumatif untuk mengukur keberhasilan peserta didik dan digunakan sebagai umpan balik bagi peserta didik.
\end{abstract}

Kata Kunci: Manajemen Strategik, Pengembangan Kurikulum, Program Unggulan, Madrasah Aliyah. 


\begin{abstract}
:
Quality of education improvement via special quality program in higher Islamic school has been participating in increasing the national education quality to respond multi-dimensional crisis, such as human resource quality and identity-morality issues. This paper attempts to provide opinion about managerial efforts in curriculum development for the special quality program in higher Islamic schools. The management involves planning, implementing, and evaluating curriculum. The planning is managed to under the framework of "SNP Plus X Adaptif Cambridge" curriculum so that the students are expected to pass The National Examination and National Science Olympiade. The implementation of curriculum refers to syllabus and lesson plans as a workshop product in the beginning of semester. The evaluation of curriculum makes use both formative and summative curriculum to maeasure students' achievement and to provide feedbacks for them.
\end{abstract}

\title{
Keywords: Strategic Management, Curriculum Development, Special Quality Program, Islamic High School.
}

\section{A. Pendahuluan}

Perkembangan ilmu pengetahuan dan teknologi telah membawa perubahan di hampir semua aspek kehidupan manusia. Dimana berbagai permasalahan "hanya dapat dipecahkan kecuali dengan upaya penguasaan dan peningkatan ilmu pengetahuan dan teknologi. Selain manfaat bagi kehidupan manusia di satu sisi perubahan tersebut juga telah membawa manusia ke dalam era persaingan global yang semakin ketat."1

Sebagai bangsa perlu meningkatkan mutu sumber daya manusia agar mampu berperan dalam persaingan global. Maka dari itu, peningkatan kualitas sumber daya manusia merupakan keniscayaan yang harus dilakukan dengan pendidikan secara terencana, terarah, intensif, efektif dan efisien. Jika bangsa ini tidak mau kalah dalam persaingan dengan negara-negara lain dalam menjalani era globalisasi tersebut.

Peningkatan mutu pendidikan merupakan proses yang terintegrasi dengan proses peningkatan kompetensi manusia itu sendiri. ${ }^{2}$ Menyadari pentingnya proses peningkatan kualitas sumber daya manusia. Maka pemerintah bersama masyarakat telah berusaha untuk mewujudkan peningkatan tersebut antara lain melalui pengembangan, perubahan, perbaikan kurikulum dan sistem

1Dewi Salma Prawiradilaga, Mozaik Tekonologi Pendidikan (Jakarta: Kencana, 2004), 142.

${ }^{2}$ Conny R. Semiawan, dan Soedijarto, Mencari Strategi Pengembangan Pendidikan Nasional Menjelang Abad XXI (Jakarta: PT. Grasindo, 1991), 26. 
evaluasi, pengembangan dan pengadaan materi ajar, perbaikan sarana pendidikan, serta pendidikan dan pelatihan bagi guru dan tenaga kependidikan lainnya. ${ }^{3}$

Pada kenyataannya upaya pemerintah dalam meningkatkan kualitas pendidikan belum menunjukkan peningkatan yang signifikan. Salah satu indikator kekurang berhasilan ini ditunjukkan antara lain dengan NUN siswa untuk berbagai bidang studi pada jenjang SMP dan SMA yang tidak memperlihatkan kenaikan yang berarti bahkan boleh dikatakan stagnan dari tahun ke tahun, kecuali pada beberapa sekolah dengan jumlah yang relatif sangat kecil."4 Bahkan akhir-akhir ini banyak sekolah yang tidak memenuhi target menjadi sekolah berintegritas. Disamping itu dalam kondisi krisis multidimensi yang berkepanjangan. Pendidikan telah menarik perhatian berbagai pihak untuk meningkatkan mutunya. Namun di banyak yang mengeluhkan mengenai tingginya biaya karena peningkatan mutu tentu diiringi dengan peningkatan biaya.

Kurikulum atau isi merupakan salah satu komponen yang memiliki peran yang cukup strategis dalam sistem pendidikan baik secara nasional maupun dalam lingkup sekolah. ${ }^{5}$ Maksud strategis ini yaitu perubahan kurikulum tentu banyak membawa perubahan yang signifikan dalam dunia pendidikan. Kurikulum dan pembelajaran adalah kegiatan inti sekolah dan pengelolaannya merupakan bagian yang sangat penting dari manajemen sekolah. Manajemen kurikulum dan kegiatan pembelajarannya mencakup kegiatan perencanaan, pelaksanaan dan penilaian kurikulum. ${ }^{6}$ Perencanaan dan pengembangan kurikulum nasional pada umumnya telah dilakukan oleh Departemen Pendidikan Nasional pada tingkat pusat. Karena itu pada level sekolah yang paling penting adalah bagaimana mengimplementasikan dan mengadaptasi kurikulum tersebut dengan kegiatan pembelajaran. Di samping itu sekolah juga bertugas dan berwenang untuk mengembangkan kurikulum sesuai dengan kondisi sekolah, karakteristik peserta didik, potensi daerah, kebutuhan masyarakat dan lingkungan setempat.

Sesuai standar Nasional pendidikan, kurikulum tingkat satuan pendidikan (KTSP) dibuat oleh sekolah atas tanggung jawab kepala sekolah atas pelaksanaan penyusunan kurikulum tingkat satuan pendidikan (KTSP). Namun

\footnotetext{
${ }^{3}$ Masnur Muslich, KTSP Pembelajaran Berbasis Kompetensi dan Kontekstual (Jakarta: Bumi Aksara, 2007), 24.

${ }^{4}$ Rachman Arief, dan Tim Konsultan Proyek Peningkatan Mutu SMU Paket- 2, Panduan Pelatihan Untuk Pengembangan Sekolah (Jakarta: Departemen Pendidikan Nasional, 2000), ii. ${ }^{5}$ Rusman, Manajemen Kurikulum (Jakarta: Rajawali Pers, 2009), 1.

${ }^{6}$ Nurdin Marty, Implementasi Dasar-dasar Manajemen Sekolah Dalam Era Otonomi Daerah (Yogyakarta: Arruz Media, 2008), 85.
} 
demikian pengembangannya yang beragam harus memperhatikan Standar Kompetensi Lulusan (SKL), Standar Isi (SI), dan peraturan pelaksanaannya, dengan kata lain Standar Isi dan Standar Kompetensi Lulusan merupakan acuan bagi satuan pendidikan dalam mengembangkan kurikulum. Dalam memenuhi amanat Undang-undang No. 20 Tahun 2003 tentang Sistem Pendidikan Nasional, pasal 36 ayat 2 dan amanat Peraturan Pemerintah No. 19 tahun 2005 tentang Standar Nasional Pendidikan (SNP), kurikulum dikembangkan secara diversifikasi oleh satuan pendidikan dengan mengacu pada standar isi yang tertuang dalam Permendiknas No. 22 Tahun 2006, dan standar kompetensi lulusan satuan pendidikan yang tertuang dalamPermendiknas No. 23 Tahun 2006, dan berpedoman pada panduan yang disusun oleh Badan Standar Nasional Pendidikan (BSNP), maka pengembangan kurikulum berdiversifikasi merupakan tantangan besar bagi sekolah. Jika selama ini kurikulum disusun secara lengkap oleh pusat dan sekolah tinggal menerapkan, tetapi sekarang sekolah dituntut mampu untuk mengembangkan kurikulum sendiri. Kebijakan tersebut menuntut sekolah untuk mampu menjabarkan standar isi yang telah diterapkan oleh pemerintah menjadi kurikulum yang diyakini cocok dengan situasi dan kondisi sekolah yang bersangkutan dan pelaksanaannya mampu mengantarkan peserta didik mencapai standar kompetensi lulusan yang telah ditetapkan.

Pemerintah Republik Indonesia menyadari tentang hal itu, sehingga upaya yang dilakukan untuk meningkatkan kualitas pendidikan terus dilakukan dari tahun ke tahun.Sebab dalam peningkatan sumber daya manusia (SDM), pendidikan memegang peranan strategis yaitu sebagai pendekatan dasar dan pengembangan sistem pembangunan bangsa. Hal ini sejalan dengan tujuan pendidikan Nasional yang ditetapkan dalam Undang-undang No. 20 tahun 2003 pasal 36 yang berbunyi:

1. Pengembangan kurikulum dengan mengaju pada standar nasional pendidikan (SNP) untuk mewujudkan tujuan pendidikan nasional.

2. Kurikulum pada semua jenjang dan jenis pendidikan dikembangkan dengan prinsip diversifikasi sesuai dengan satuan pendidikan, potensi daerah dan karakteristik siswa.

3. Kurikulum tingkat satuan pendidikan dasar dan menengah dikembangkan oleh sekolah dan komite sekolah berpedoman pada standar kompetensi kelulusan (SKL) dan standar isi (SI), serta panduan penyusunan kurikulum yang dibuat oleh Badan Standar Nasional Pendidikan (BSNP). ${ }^{7}$

Sejalan dengan tujuan pendidikan Nasional tersebut diatas, pemerintah terus berusaha untuk mewujudkan sekolah-sekolah yang mandiri, bermutu dan

${ }^{7}$ Marty, Implementasi Dasar-dasar, 85. 
mempunyai tanggung jawab sosial terhadap masyarakat sekitar. Dengan bergulirnya sistem desentralisasi pendidikan, maka sebagian besar tugas dan tanggung jawab penyelenggarakan pendidikan juga dialihkan dari pemerintah pusat ke pemerintah daerah. Dengan demikian, untuk mewujudkan daerah yang maju maka diperlukan kualitas pendidikan yang baik di daerah itu. Salah satu komponen penting dari sistem pendidikan nasional tersebut adalah kurikulum.Kurikulum merupakan komponen pendidikan yang dijadikan acuan bagi setiap satuan pendidikan. Bagi pengelola maupun penyelenggara khususnya guru dan kepala sekolah. Jika kurikulum merupakan acuan dalam pembelajaran kemudian materi yang dikembangkan dari kurikulum diberlakukan tepat dan benar, maka akan terjadi hubungan harmonis antara kurikulum dan guru sebagai pelaksana. Di era otonomi daerah, penyelenggaraan pendidikan berusaha pengembalikan pendidikan kepada masyarakat. Otonomi daerah berimplikasi pada otonomi pendidikan. Otonomi penyelenggaraan pendidikan pada gilirannya berimplikasi kepada perubahan system manajemen pendidikan dari pola sentralisasi ke desentralisasi dalam pengelolaan pendidikan. Sebagai implikasi selanjutnya adalah dikembangkannya pendidikan yang demokratis dan monopololistik dalam menentukan jenis muatan kurikulum.

Bermunculannya lembaga pendidikan baru menimbulkan fenomena dalam dunia pendidikan.Bentuk dan pendekatan pendidikan semakin berkembang dan kompleks, bahkan model pembelajarannyapun juga berkembang. Secara objektif, masyarakat dihadapkan dalam berbagai pilihan yang secara otomatis menyebabkan semakin sulitnya menentukan pilihan lembaga pendidikan formal/sekolah untuk anaknya.

Paparan kondisi pendidikan di atas, menunjukkan bahwa sekolah memainkan peranan yang penting dan menentukan keberlangsungan serta perkembangan sekolah itu dimasa yang akan datang. Pembangunan pendidikan bukan hanya terfokus pada penyediaan faktor input pendidikan tetapi juga harus lebih memperhatikan faktor proses pendidikan.

Input pendidikan merupakan hal yang harus baik tetapi tidak menjadi assuranceyang dapat secara otomatis meningkatkan mutu pendidikan (school resources are necessary but not sufficient condition to improve student achievement). Mestinya, jika input baik, maka output juga baik. Namun hal itu bukanlah jaminan jika prosesnya tidak diperbaiki. Di samping itu mengingat sekolah sebagai garda terdepan dengan berbagai input yang masuk dengan berbagai jenis keragaman potensi anak didik yang memerlukan layanan pendidikan yang beragam, kondisi lingkungan yang berbeda satu dengan lainnya, maka sekolah harus mampu mengupayakan pelayanan tersebut, yang dinamis 
dan kreatif dalam melaksanakan perannya untuk mengupayakan peningkatan kualitas/mutu pendidikan dan dalam menekan biaya pendidikan.

Hal ini akan dapat dilaksanakan jika "sekolah dengan berbagai keragamannya itu, diberikan kepercayaan untuk mengatur dan mengurus dirinya sendiri sesuai dengan kondisi lingkungan dan kebutuhan anak didiknya."8 Walaupun demikian, agar mutu tetap terjaga dan agar proses peningkatan mutu tetap terkontrol, maka harus ada standar yang diatur dan disepakati secara secara nasional untuk dijadikan indikator evaluasi keberhasilan peningkatan mutu tersebut (adanya benchmarking).

Sekolah adalah perwujudan dari organisasi pendidikan yang mempunyai tujuan untuk mendidik anak manusia. Organisasi pada hakikatnya merupakan institusi pencipta kekayaan (wealthcreating institution). Dalam lingkungan bisnis yang kompetitif, organisasi tidak hanya diharapkan sebagai institusi pencipta kekayaan, namun jauh lebih dari itu; organisasi diharapkan sebagai institusi pelipatganda kekayaan (wealth multiplying institution). Pelipatgandaan kekayaan memerlukan langkah-langkah besar dan cemerlang.

Kemampuan personil organisasi dalam merumuskan langkah-langkah besar dan cemerlang ditentukan oleh: (1) kompetensi personil dalam mengubah intangible assets menjadi tangible assets, dan (2) sistem manajemen. Human capital, information capital, dan organization capital merupakan intangible assets yang menjadi pemacu kinerja keuangan organisasi modern.Kompetensi personil dalam mengubah intangible assets tersebut menjadi value bagi customer merupakan pemacu dihasilkannya kinerja keuangan luar biasa berkesinambungan.Seringkali yang terjadi adalah kompetensi personil dalam mengelola intangible assets tersebut terhambat oleh sistem manajemen yang digunakan oleh organisasi. ${ }^{9}$

Akhir-akhir ini semakin banyak pihak yang merasakan bahwa pendidikan Islam belum memenuhi harapan yang diinginkan. Madrasah yang ada juga kurang memberikan arti, namun malah memberikan output yang mogol. Pendidikan Islam mengalami stagnan dan memendam banyak persoalan. Hal demikian menumbuhkan minat sebagian pelaksana pendidikan untuk mengadakan pembaharuan dan peningkatan kualitas pendidikan Islam secara terus-menerus. Berbagai tulisan dalam bentuk buku, majalah, jurnal, diupayakan.

Kemudian munculah bermacam bentuk lembaga pendidikan Islam unggulan, baik melalui jalur sekolah dan luar sekolah, seperti Pesantren Modern

${ }^{8}$ Dikmenum, Peningkatan Mutu Pendidikan Berbasis Sekolah: Suatu Konsepsi Otonomi Sekolah (Jakarta: Depdikbud, 1999), 2.

${ }^{9}$ Victorian's Departement of Education, How Good is Our School: School Performance for School Councillors (Australia, Melbourne, 1998), 256. 
Gontor Ponorogo, Azzaitun Indramayu, Sekolah Menengah Umum (SMU) Insan cendekia Jakarta, SMU Internat Al Kautsar Sukabumi, dan sebagainya. Tentu lembaga pendidikan ini mempunyai manajemen sendiri dalam pengembangan kurikulum lembaga pendidikannya. Bentuk-bentuk pendidikan di atas merupakan perwujudan usaha-usaha nyata dalam rangka meningkatkan kualitas pendidikan Islam yang diharapkan mampu menjawab tantangan zaman, sekarang dan masa depan sesuai dengan arah kebijakan pendidikan nasional. Maka dari itu, di lembaga pendidikan Islam juga dikembangkan konsep kurikulum dengan program unggulan.

\section{B. Konsep Dasar Kurikulum}

Kata kurikulum bukan berasal dari bahasa Indonesia, namun berasal dari bahasa Yunani yang semula dipakai dalam bidang olah raga, yaitu curere yang berarti jarak lari paling jauh yakni jarak yang harus ditempuh dalam kegiatan lomba lari sepenuhnya. ${ }^{10}$ Dalam bukunya, Ramayulis mengutip dari Langgulung yang menyatakan bahwa kurikulum berasal dari kata curir yang berarti orang yang lari dan curare yang berarti tempat berpacu. ${ }^{11}$ Kurikulum juga diambil dari kata Chariot yang berarti semacam kereta pacu pada zaman dahulu. ${ }^{12}$ Jika dalam dunia pendidikan, maka konteksnya berubah yakni suatu materi yang harus ditempuh oleh peserta didik dan pendidik yang sedang melakukan kegiatan pembelajaran.

Menurut Harsono, kurikulum merupakan gagasan atau materi pendidikan yang ideal yang diekpresikan dalam praktik kegiatan pembelajaran. Saat ini definisi kurikulum semakin berkembang, sehingga yang dimaksud kurikulum tidak hanya gagasan pendidikan yang ideal tetapi juga termasuk seluruh program pembelajaran yang terencana dari suatu institusi pendidikan. ${ }^{13}$ Menurut Grayson, kurikulum adalah suatu perencanaan (planning) untuk menjadikan keluaran (outcomes) yang diharapkan dari suatu pembelajaran melalui konsep pendidikan. Perencanaan tersebut disusun secara terstruktur untuk suatu mata pelajaran, sehingga memberikan pedoman dan instruksi untuk mengembangkan model, pendekatan, metode, teknik dan strategi pembelajaran.

10 Samsul Nizar, Filsafat Pendidikan Islam: Pendekatan Historis, Teoritis dan Praktis (Jakarta: Ciputat Pers, 2002), 55.

${ }^{11}$ Ramayulis, Ilmu Pendidikan Islam (Jakarta: Kalam Mulia, 2006), 150.

12 Nasution, Asas-asas Kurikulum (Jakarta: Bumi Aksara, 2003),1-2. Lihat juga Khoiron Rosyadi, Pendidikan Profetik (Yogyakarta: Pustaka Pelajar, 2004), 240.

${ }^{13}$ Harsono, Pengantar Problem-Based Learning (Yogyakarta: Medika, 2005), 9 
Materi di dalam kurikulum harus diorganisasikan dengan baik agar sasaran (goals) dan tujuan (objectives) pendidikan yang telah ditetapkan dapat tercapai. ${ }^{14}$ Dari definisi tersebut di atas, inti dari kurikulum, terdapat tiga pilar yang sedang berlangsung yaitu: 1) Adanya proses pengajaran, 2) Fasilitasi peserta didik untuk belajar, sebagai proses pembelajaran peserta didik, dan 3) Informasi baru yang didapat peserta didik sebagai hasil interaksi antara pendidik dan peserta didik sebagai hasil dari proses pembelajaran.

\section{Model Pengembangan Kurikulum}

Dalam kegiatan pengembangan kurikulum, model pengembangan kurikulum merupakan ulasan teoritis tentang pengembangan kurikulum secara menyeluruh ataupun hanya sebagian komponen kurikulum. Diantaranya adalah sebagaimana yang dikemukakan oleh Sukmadinata berikut ini:

1. The Administration model.Model ini disebut juga line staff karena inisiatif dan gagasan pengembangan datang dari para administrator pendidikan dan menggunakan prosedur administrasi. Model ini memiliki langkah-langkah kerja antara lain: a) administrator pendidikan membentuk komisi mengarah, b) komisi pengarah (stering komite) merumuskan rencana umum dan landasan filosofis serta tujuan untuk seluruh wilayah sekolah, c) membentuk komisi kerja pengembangan kurikulum secara operasional, d) membentuk komisi pengarah memeriksa hasil kerja komisi kerja dan menyempurnakan bagian-bagian tetentu yang dianggap perlu penyempurnaan. Karena sifatnya yang datang dari atas, maka model ini juga disebut model "top down atau"line staff."

2. The grass roots model. Upaya pengembangan model ini adalah yang berasal dari bawah, yaitu guru-guru atau sekolah. Ada empat prinsip yang digunakan dalam model ini yaitu, a) kurikulum akan bertambah baik kalau kompetensi profesi guru bertamabah baik. b) kompetensi guru bertambah baik kalau guru menjadi personil-personil yang dilibatkan dalam perbaikan kurikulum, c) jika guru bersama-sama bertanggung jawab atas suatu yang menjadi tujuan yang dicapai, dalam memilih dan memecahkan masalah yang dihadapi serta dalam memutuskan dan menilai hasil, keterlibatan mereka akan lebih terjamin, d) sebagai oarang yang bertemu dalam kelompok tatap muka mereka akan mengerti satu sama lain dan membantu adanya konsensus dalam prinsip-prinsip dasar, tujuan dan perencanaan.

3. Beauchamp's system. Teori ini diprakarsai oleh Beauchamps, yang mengemukakan ada lima langkah penting dalam pengembangan kurikulum, yaitu, a) menentukan arena pengembangan kurikulum yang dilakukan, yang berupa kelas, system persekolahan regional atau nasional, b) menetapkan personalia, yaitu siapa yang turut serta terlibat dalam

14 Grayson Lawrence, On a Methodology for Curriculum Design (Engineering Education, 1978), 15. 
pengembangan kurikulum, c) mengorganisasikan dan menentukan prosedur perencanaan kurikulum yang meliputi penentuan tujuan, materi pelajaran dan kegiatan belajar secara sistematis di sekolah, d) melaksanakan kurikulum yang membutuhkan kesiapan semua pihak, mulai dari guru, siswa fasilitas, biaya dan manajerial dari pimpinan sekolah dan adminstrator, e) melakukan evaluasi terhadap pelaksanaan kurikulum oleh guru, desain kurikulum, hasil belajar siswa dan keseluruhan sistem kurikulum.

4. The demonstration model. Model ini juga bersifat grass roots, atau dari bawah yang diprakarsai oleh guru dan bekerjasama dengan para ahli. Model ini pada umumnya berskala kecil, hanya mencakup keseluruhan komponen kurikulum.

5. Taba's inverted model. Langkah- langkah pengembangan kurikulum model Taba yaitu: mengadakan unit-unit eksperimen bersama-sama guru, mengadakan revisi dan konsolidasi, menguji unit eksperimen, cmengadakan revisi dan konsolidasi, pengembangan keseluruhan kerangka kurikulum, dan implementasi dan diseminasi.

6. Roger's interpersonal relations model. Rogers menawarkan empat langkah pengembangan kurikulum yaitu: pemilihan target dan sistem pendidikan, partisipasi guru dalam pengalaman kelompok yang intensif, pengembangan pengalaman kelompok yang intensif, pengembangan pengalaman kelompok yang intensif untuk satu kelas atau unit pelajaran, dan melibatkan orang tua dalam pengalaman kelompok yang intensif.

7. Emerging technical models. Model ini melibatkan kepribadian orang tua, siswa, guru, struktur sistem sekolah, pola hubungan pribadi dan kelompok dari sekolah dan masyarakat. Ada dua langkah yang dilakukan yaitu: a) mengadakan kajian secara saksama tentang masalah kurikulum, berupa pengumpulan data yang bersifat menyeluruh dan mengidentifikasi faktorfaktor, kekuatan dan kondisi yang mempengaruhi masalah tersebut, b) implementasi dari keputusan yang diambil dalam tindakan pertama.

8. Emerging technical models. Perkembangan bidang teknologi dan ilmu pengetahuan serta nilai-nilai efisiensi efektivitas dalam bisnis, juga mempengaruhi perkembangan model-model kurikulum..$^{15}$

\section{Proses Pengembangan Kurikulum}

Kurikulum adalah sebuah rencana yang dibuat dengan mendasarkan berbagai kondisi yang ada untuk mencapai suatu tujuan pendidikan. Oleh sebab itu proses pembuatan dan pengembangan kurikulum merupakan sebuah proses berantai yang berkesinambungan antara proses yang satu dengan proses yang lain. Lebih lanjut Muhaimin mengemukakan bahwa kurikulum sebagai suatu rencana pada intinya adalah upaya untuk menghasilkan lulusan, atau mengubah

\footnotetext{
${ }^{15}$ Nana Syaodih Sukmadinata, Pengembangan Kurikulum, Praktek dan Teori, (Bandung: Remaja Rosdakarya, 2007), 161-170.
}

Jurnal Pendidikan Agama Islam

Volume 4 Nomor 1 Mei 2016

ISSN(p) 2089-1946\& ISSN(e) 2527-4511

Hal. 100 - 115 
input peserta didik dari kondisi awal menjadi peserta didik yang memiliki kriteria;16 1) mampu memahami konsep yang mendasari standar kompetensi yang harus dikuasai, 2) mampu melakukan pekerjaan sesuai dengan tuntutan standar kompetensi yang harus dicapai dengan cara dan prosedur yang benar serta hasilyang baik, dan 3) mampu mengaplikasikan kemampuanya dalam kehidupan sehari-hari (didalam maupundi luar sekolah). Dengan demikian kompetensi merupakan kombinasi yang baik dari penguasaan ilmu (knowledge), ketrampilan dalam melaksanakan pekerjaan (skill), dan sikap yang dituntutuntuk menguasai suatupekerjaan (attitude). Tanpa memiliki 3 kriteria di atas, maka mustahil suatu kurikulum disebut sebagai kurikulum yang baik.

Hamalik, membagi proses pengembangan kurikulum dalam dua jenis proses, yakni pengembangan dalam arti perekayasaan (engineering) dan pengembangan dalam arti konstruksi. ${ }^{17}$ Proses pengembangan dalam arti pertama, terdiri dari empat tahap; konstruksi ialah mengembalikan model kurikulum yang diharapkan berdasarkan dasar yang telah direncanakan tersebut; implementasi ialah pelaksanaan kurikulum; dan evaluasi ialah menilai kurikulum secara komperenhesif dan sistematik apakah sudah dilaksanakan atau belum dilaksanakan.

Pada umumnya para ahli kurikulum memandang kegiatan kurikulum sebagai suatu proses yang terus- menerus dan merupakan suatu siklus yang menyangkut beberapa komponen kurikulum yaitu komponen tujuan, bahan, kegiatan dan evaluasi. Pengembangan kurikulum merupakan proses yang komprehensif, yang meliputi kegiatan perencanaan, implementasi, dan evaluasi. Mengacu pada siklus pengembangan kurikulum tersebut diatas juga dapat diketahui bahwa pengembangan kurikulum pada hakekatnya adalah pengembangan komponen kurikulum yang membentuk sistem kurikulum itu sendiri, yaitu tujuan, bahan, kegiatan, dan evaluasi. Hal ini dilakukan agar kurikulum dapat berjalan sesuai dengan apa yang diharapkan dalam usaha mencapai tujuan pendidikan yang ditetapkan.

Berdasarkan penilaian dan pemantauan kurikulum diperoleh data informasi yang akurat. Selanjutnya digunakan sebagai bahan untuk melakukan perbaikan pada kurikulum tersebut bila diperlukan, melakukan penyesuaian kurikulum dengan keadaan.

Berdasarkan beberapa pendapat diatas, dapat disimpulkan bahwa prosese pengembangan kurikulum tidak sederhana selama ini dilakukan oleh

16Muhaimin, Pengembangan Kurikulum Pendidikan Agama Islam (Jakarta: Raja Grafindo Persada, 2005), 234

170emar Hamalik, Dasar-dasar Pengembangan Kurikulum (Jakarta: Remaja Rosdakarya, 2006), 109 
Tim Pengembangan Kurikulum (TPK). Pengembangan kurikulum ternyata mempunyai rambu-rambu yang harus dipatuhi dengan seksama. Ketika pengembang kurikulum tidak mengikuti aturan atau prosedur yang di tetapkan akan mengakibatkan penyimpangan-penyimpangan yang berakibat kualitas pendidikan tidak mencapai hasil yang maksimal.

\section{E. Program Unggulan}

Pada pertengahan 1990 di Indonesia muncul istilah sekolah unggul (excellent schools) yang tumbuh bagaikan jamur. Perkembangan ini pada awalnya dirintis sekolah-sekolah swasta termasuk sekolah-sekolah Islam dengan ditandai biaya yang tinggi, fasilitas lux, elitis, eksklusif, dan dikelola tenagatenaga yang profesional.

Gerakan keterunggulan (excellence movement) ini kemudian dikembangkan dan diejawantahkan oleh pengelola pendidikan tingkat satuan pendidikan (sekolah) dalam bentuk-bentuk sekolah yang mempunyai trademark di masyarakat. Misalnya, sekolah plus, sekolah unggulan, sekolah alam, sekolah terpadu, sekolah eksperimen (laboratorium), sekolah full day, dan label-label lain yang melekat pada sekolah yang diasumsikan dengan mengedepankan program unggulan.

Sekolah dengan model ini sangat diminati masyarakat modern yang nota bene mempunyai kesibukan di luar rumah (bekerja), sehingga perhatian terhadap keluarga khususnya pendidikan agama anak-anak sangat kurang. Sekolah model ini dapat menjadi solusi bagi pembinaan kegiatan keagamaan maupun kegiatan lainnya untuk anak.

Usaha pengembangan sekolah model ini penting dilakukan, senyampang tidak meninggalkan aspek-aspek peningkatan mutu pendidikan. Misalnya, pembinaan prestasi akademik harus selalu ditingkatkan dengan memberikan jadwal remedial secara kolektif atau secara individu bagi anak-anak yang kurang mampu dalam mengikuti pelajaran di kelas, sehingga anak benar-benar sangat menguasai pelajaran.Pembinaan prestasi non akademik melalui berbagai kegiatan ekstra kurikuler harus terus ditingkatkan.Seluruh potensi siswa sebisa mungkin dapat digali dan disalurkan serta diasah sehingga kelak setiap siswa dapat mempunyai bidang ketrampilan (bekal hidup) yang ditekuni secara profesional sesuai minat dan bakatnya.

Peningkatan mutu dan kualitas tenaga pengajar, sarana prasarana belajar termasuk perpustakaan dan laboratorium serta sumber-sumber belajar lainnya. Memberikan teladan dalam melaksakan school culture sehingga siswa memiliki karakter yang tangguh dalam menjalankan keyakinan agamanya. Dan menjalin kerjasama antara sekolah dan masyarakat dalam meningkatkan mutu sekolah. 
Sekolah pada masa depan adalah sekolah yang dikelola secara modern (modern schools). Salah satu ciri dari sekolah modern adalah mengutamakan kualitas. Kualitas yang dimaksudkan diukur dengan pencapaian skor tes prestasi tinggi dalam bidang akademik (mastery of basic skill) dan juga pertumbuhan dan perkembangan sosial anak secara baik sesuai dengan pencapaian tujuan pendidikan yang telah ditetapkan (goal attainment). Proses manajemen pembelajaran dan sekolah juga menjadi faktor determinan yang sering disebut sebagai karakteristik sekolah (school characteristics), juga respon lingkungan yang positif menjadi faktor pendukung lain yang tidak dapat diabaikan. Iklim yang sehat, dukungan orang tua murid dan masyarakat yang tinggi terhadap program sekolah, dan kepemimpinan yang kolaboratif partisipatif menjadi salah satu bagian sangat berarti, terutama pada sekolah yang memiliki murid multi etnik/multi kultur. Mutu suatu lembaga pendidikan Islam bisa dilihat dari rumusan visi dan misinya, yang kemudian visi dan misi tersebut diwujudkan dalam proses pendidikan yang akan dilakukan. Menurut Muhaimin mutu Lembaga pendidikan yang dimaksud adalah sebagai berikut: Kesesuaian dengan standar; Kesesuaian dengan harapan stakeholders, atau Pemenuhan janji yang telah diberikan. ${ }^{18}$

Universitas Gadjah Mada menambahkan pengertian mutu lembaga pendidikan sebagai berikut: Sesuai dengan "standar"; Sesuai harapan dengan "pelanggan"; Sesuai dengan harapan "pihak-pihak terkait"; Sesuai dengan yang dijanjikan; semua karakteristik produk dan pelayanan yang memenuhi persyaratan dan harapan. ${ }^{19}$ Sekolah unggulan memiliki karakteristik keunggulan yang ditunjukkan dengan pengakuan internasional terhadap proses dan hasil atau keluaran pendidikan yang berkualitas dan teruji dalam berbagai aspek. Pengakuan internasional ditandai dengan penggunaan standar pendidikan internasional dan dibuktikan dengan hasil sertifikasi berpredikat baik dari salah satu negara anggota OECD dan/atau negara maju lainnya yang mempunyai keunggulan tertentu dalam bidang pendidikan.

Visi, misi dan tujuan lembaga pendidikan Islam pun juga masih belum berhasil dirumuskan dengan baik. Tujuan lembaga pendidikan Islam seringkali diarahkan untuk menghasilkan manusia-manusia yang hanya menguasai ilmu Islam an-sich, dan visinya diarahkan untuk mewujudkan manusia yang salih dalam arti yang taat beribadah dan gemar beramal untuk tujuan akhirat. Akibat dari keadaan yang demikian ini, maka para lulusan lembaga pendidikan Islam

${ }^{18}$ Muhaimin, Manajemen Penjaminan Mutu di Universitas Islam Negeri Malang (Malang: UIN, 2005), 10.

${ }^{19}$ Universitas Gajah Mada, Sistem Penjaminan Mutu Perguruan Tinggi (Yogyakarta: UGM, 2004), 5 . 
hanya memiliki kesempatan dan peluang yang cukup terbatas, yaitu hanya sebagai pengawal moral bangsa. Mereka kurang mampu bersaing dan tidak mampu merebut peluang dan kesempatan yang tersedia dalam memasuki lapangan kerja, akibatnya lulusan lembaga pendidikan Islam semakin termarginalisasikan dan tidak berdaya.

Pendidikan yang bermutu adalah pendidikan yang mampu menghasilkan lulusan yang memiliki kemampuan atau kompetensi, baik kompetensi akademik maupun kompetensi kejuruan, yang dilandasi oleh kompetensi personal dan sosial, yang secara menyeluruh disebut sebagai kecakapan hidup (life skill). Pendidikan kecakapan hidup adalah pendidikan yang bermutu, baik quality in fact maupun quality in perception. ${ }^{20}$ Untuk dapat meningkatkan mutu pendidikan, maka lembaga pendidikan Islam harus dapat melaksanakan pengelolaan yang didasarkan pada peningkatan mutu lembaga pendidikan Islam.

Aplikasi dari manajemen peningkatan mutu terhadap lembaga pendidikan Islam didasarkan atas pemikiran bahwa para administrator dan manajer pendidikan perlu menemukan kerangka kerja yang muncul dari dalam lembaga pendidikan itu yang diperkirakan dapat menopang mutu dan kinerja lembaga pendidikan yang menjadi tanggung jawab mereka. ${ }^{21}$ Dalam meningkatkan mutu pendidikan, Bennet mengidentifikasikan prinsip-prinsip dasar tentang mutu yaitu:22 (1) definisi kualitas lebih mengacu pada konsumen, bukan pada pemasok, (2) konsumen adalah seseorang yang memperoleh produk atau layanan, seperti mereka yang secara internal dan eksternal terkait dengan lembaga pendidikan dan bukannya yang hanya menjadi "pembeli" atau "pembayar", (3) mutu harus mencukupi persyaratan kebutuhan dan standar, (4) mutu dicapai dengan mencegah kerja yang tidak memenuhi standar, bukannya dengan melacak kegagalan melainkan dengan peningkatan layanan dan produk yang terus menerus, (5) peningkatan mutu dikendalikan oleh manajemen tingkat senior, namun semua yang terlibat di dalam lembaga pendidikan harus ikut bertanggung jawab, mutu harus dibangun di dalam setiap proses, (6) mutu diukur melalui proses statistik, anggaran mutu adalah anggaran biaya yang tidak disesuaikan dengan tuntutan persyaratan, sehingga terjadi kesenjangan antara dua penyerahan barang, (7) alat yang paling ampuh untuk menjamin terjalinnya mutu adalah kerjasama (tim) yang efektif, dan (8) pendidikan dan pelatihan merupakan hal yang fundamental terhadap lembaga pendidikan yang bermutu.

${ }^{20}$ H. Sudrajad, Manajemen Peningkatan Mutu Berbasis Sekolah (Bandung: CV. Cipta Cekas Grafika, 2005), 17.

${ }^{21}$ W. Manjta, Manajemen Pendidikan dan Supervisi Pengajaran (Malang: Wineka Media, 2002), 33-34.

${ }^{22} \mathrm{M}$. Crawford N. Bennet dan C. Riches, Managingange in Education: Individual and Organization Perspektif , (London: Paul Chapman Publishing Co, 1992), 56. 
Peningkatan mutu harus bertumpu pada lembaga pendidikan untuk secara terus menerus dan berkesinambungan untuk meningkatkan kapasitas dan kemampuan lembaga pendidikannya guna memenuhi tuntutan dan kebutuhan peserta didik dan stakeholders. Dalam manajemen peningkatan mutu terkandung upaya: (1) mengendalikan proses yang berlangsung di lembaga pendidikan baik kurikuler maupun administrasi, (2) melibatkan proses diagnose dan proses tindakan untuk menindaklanjuti diagnose, (3) peningkatan mutu harus didasarkan atas data dan kata, baik yang bersifat kualitatif maupun kuantitatif, (4) peningkatan mutu harus dilaksanakan secara terus menerus dan berkesinambungan, (5) peningkatan mutu harus memberdayakan dan melibatkan semua unsur yang ada dalam lembaga pendidikan, dan (6) peningkatan mutu memiliki tujuan yang menyatakan bahwa sekolah atau madrasah dapat memberikan kepuasan kepada peserta didik, orang tua dan masyarakat. Tuntutan peningkatan mutu suatu produk atau layanan jasa termasuk pendidikan oleh pelanggan terus terus menerus berkembang dan meningkat dari waktu ke waktu, dari tahun ke tahun dan dari jaman ke jaman. Masyarakat semakin cerdas dalam memilih lembaga pendidikan, mereka dapat membedakan lembaga pendidikan/sekolah yang berkualitas dan kurang berkualitas. Oleh karena itu, penyelenggara/pengelola sekolah/madrasah atau lembaga pendidikan tidak bisa menyelenggarakan pendidikan asal jadi dan statis tanpa perbaikan berkesinambungan memenuhi tuntutan dan kebutuhan masyarakat.23

Penyelenggaraan lembaga pendidikan pada sekolah ataupun madrasah dituntut untuk memenuhi atau melebihi kebutuhan atau keinginan pelanggannya, melibatkan secara total semua komponen sekolah, mengadakan pengukuran dan evaluasi diri terhadap kemaajuan lembaga pendidikan yang dikelalolanya, peningkatan atau perbaikan mutu pendidikan yang diselenggarakannya secara menyeluruh terhadap semua komponen/subsubsistem lembaga pendidikan dan mengadakan berbaikan mutu pendidikan secara berkesinambungan untuk menyesuaikan dengan tuntutan perkembangan jaman dan memenuhi atau melebihi harapan, keinginan dan kebutuhan pelanggannya.

Sebutan sekolah unggulan itu sendiri kurang tepat. Kata "unggul" menyiratkan adanya superioritas dibanding dengan yang lain. Kata ini menunjukkan adanya "kesombongan" intelektual yang sengaja ditanamkan di lingkungan sekolah. Di negara-negara maju, untuk menunjukkan sekolah yang

${ }^{23}$ W. Manjta, Manajemen Pendidikan, 30. 
baik tidak menggunakan kata unggul (excellent) melainkan effective, develop, accelerate, dan essential. ${ }^{24}$

\section{F. Manajemen Pengembangan Kurikulum Program Unggulan}

1. Perencanaan Pengembangan Kurikulum Program Unggulan

Kurikulum yang digunakan untuk program akselerasi adalah KTSP dan tidak berbeda dengan kurikulum regular, tetapi dalam pelaksanaannya ada perbedaan, terutama pada alokasi waktu maupun kegiatan pembelajaran. Hanya saja perbedaannya kelas akselerasi lebih dipadatkan waktunya.

Planning atau perencanaan adalah keseluruhan proses danpenentuan secara matang tentang hal-hal yang akan dikerjakan di masaakan datang dalam rangka pencapaian tujuan yang telah ditentukan. ${ }^{25}$ Perencanaan merupakan keseluruhan proses pemikiran dan penentuan secara matang tentang hal-hal yang akan dikerjakan di masa yang akandatang dalam rangka mencapai tujuan yang telah ditentukan. ${ }^{26} \mathrm{Di}$ dalamperencanaan ini dirumuskan dan ditetapkan seluruh aktivitas lembaga yang menyangkut apa yang harus dikerjakan, mengapa dikerjakan, di mana dikerjakan, kapan akan dikerjakan, siapa yang mengerjakan dan bagaimana hal tersebut dikerjakan. Kegiatan yang dilakukan dalam perencanaan dapat meliputi penetapan tujuan, penegakan strategi, dan pengembangan rencana untuk mengkoordinasikan kegiatan. Kepala sekolah sebagai top management di sekolah mempunyai tugas untuk membuat perencanaan, baik dalam bidang program pembelajaran dan kurikulum, guru dan kepegawaian, kesiswaan, keuangan maupun perlengkapan. ${ }^{27}$

Perencanaan kurikulum adalah perencanaan kesempatankesempatan belajar yang dimaksudkan untuk membina siswa ke arah perubahan tingkah laku yang diinginkan dan menilai sampai mana perubahan-perubahan telah terjadi pada diri siswa. Kurikulum adalah semua pengalaman yang mencakup yang diperoleh baik dari dalam maupun dari luar lembaga pendidikan yang telah direncanakan secara sistematis dan terpadu, yang bertujuan untuk mempersiapkan peserta didik mencapai tujuan pendidikan. ${ }^{28}$

Di dalam perencanaan kurikulum minimal ada lima hal yang memengaruhi perencanaan dan pembuatan kuputusan, yaitu filosofis, konten/materi, manajemen pembelajaran, pelatihan guru, dan system

\footnotetext{
${ }^{24}$ Susan Albers Mohrman, et.al., School Based Management: Organizing for High Performance, (San Francisco: Mc Gill Publishing, 1994), 81.

${ }^{25}$ AW. Widjaya, Perencanaan sebagai Fungsi Manajemen, (Jakarta. PT Bina Aksara, 1987), 33.

${ }^{26}$ Sondang P. Siagian, Fungsi-Fungsi Manajerial (Jakarta: Penerbit Bumi Aksara, 1992), 50.

${ }^{27}$ Ngalim Purwanto, Administrasi dan Supervisi Pendidikan (Bandung: Penerbit PT. Remaja Rosdakarya, 1998), 107.

${ }^{28}$ Oemar Hamalik, Manajemen Pengembangan Kurikulum, (Jakarta: Remaja Rosda Karya, 2008), 152.
} 
pembelajaran. ${ }^{29}$ Kegiatan pertama yang dilakukan dalam perencanaan pengembangan kurikulum program adalah dengan analisis konteks, yaitu menganalisis kedelapan standar, salah satunya di dalam kurikulum ialah melakukan analisis standar isi, standar kompetensi lulusan, analisis standar proses, analisis standar penilaian, analisis standar pendidik dan tenaga kependidikan, analisis standar pengelolaan, analisis sarana dan prasarana, dan analisis standar pembiayaan. Dari analisis konteks ini mensejajarkan kedua kurikulum tersebut untuk melihat apakah kurikulum nasional dan internasional ada kesamaan atau tidak. Kalau ada kesamaan, maka bisa jadi hanya mengadaptasikan dengan kurikulum nasional dengan melihat standar yang ada. Akan tetapi kalau tidak sama, dalam arti dikurikulum nasional topik atau materinya tidak ada, maka mengadopsi kurikulum internasional dalam hal ini Cambridge.

Kurikulum adalah semua pengalaman yang telah direncanakan untuk mempersiapkan siswa mencapai tujuan pendidikan. Perencanaan kurikulum mencakup pengumpulan, pembentukan, sintesis, menyeleksi informasi yang relevan dari berbagai sumber. Kemudian informasi yang didapat digunakan untuk mendesain pengalaman belajar sehingga siswa dapat memperoleh tujuan kurikulum yang diharapkan.

Adapun perencanaan kurikulum yang dilakukan dalam mencapai tujuan kurikulum adalah kurikulum yang digunakan adalah kurikulum SNP plus $\mathrm{X}$ adaptif Cambridge, sehingga siswanya dapat mengikuti ujian Cambridge, sukses ujian nasional dan sukses OSN (olimpiade sains naional) dengan membedah SKL mulai dari kelas X.

Tujuan perencanaan kurikulum dikembangkan dalam bentukkerangka teori dan penelitian terhadap kekuatan sosial, pengembangany masyarakat, kebutuhan, dan gaya belajar siswa. Beberapa keputusan harus dibuat ketika merencanakan kurikulum dan keputusan tersebut harus mengarah pada spesifikasi berdasarkan kriteria. Merencanakan pembelajaran merupakan bagian yang sangat penting dalam perencanaan kurikulum karena pembelajaran mempunyai pengaruh terhadap siswa daripada kurikulum itu sendiri.

Kurikulum yang akan dipelajari oleh setiap individu siswa merupakan hasil pengalaman yang diperoleh dari partisipasi mereka dalam proses belajar yang dilakukan guru. Jadi, masing-masing siswa mempunyai peran di dalam menentukan kurikulum yang didasarkan pada pengalamannya.

Perencanaan kurikulum sangat tergantung pada pengembangan kurikulum dan tujuan kurikulum yang akan menjadi penghubung teori-teori pendidikan yang digunakan. ${ }^{30}$ Menurut Oemar Hamalik, perencanaan

\footnotetext{
${ }^{29}$ Rusman, Manajemen Kurikulum, 21.

${ }^{30}$ Rusman, Manajemen Kurikulum, 21.
} 
kurikulum adalah suatu proses sosial yang kompleks yang menuntut berbagai jenis dan tingkat pembuatan kuputusan. ${ }^{31}$

Selain itu perencanaan kurikulum memiliki fungsi sebagai berikut ${ }^{32}$ :

a. Perencanaan kurikulum berfungsi sebagai pedoman atau alat manajemen, yang berisi petunjuk tentang jenis dan sumber peserta yang diperlukan, media penyampaiannya, tindakan yang perlu dilakukan, sumber biaya, tenaga, sarana yang diperlukan, system control dan evaluasi, peran unsur-unsur ketenagaan untuk mencapai tujuan manajemen organisasi.

b. Perencanaan kurikulum berfungsi sebagai penggerak roda organisasi dantata laksana untuk menciptakan perubahan dalam masyarakat sesuaidengan tujuan organisasi. Perencanaan kurikulum yang matang, besar sumbangannya terhadap pembuatan keputusan oleh pimpinan, dan oleh karenanya perlu memuat informasi kebijakan yang relevan, di samping seni kepemimpinan dan pengetahuan yang telah dimilikinya.

c. Perencanaan kurikulum berfungsi sebagai motivasi untuk melaksanakan sistem pendidikan sehingga mencapai hasil optimal.

Unsur utama dalam perancanaan pengembangan kurikulum program unggulan adalah SDM dan kesamaan visi dari semua elemen yang ada. Untuk itu, untuk meingkatkan mutu pendidikan, melaksanakan workshop untuk menyusun kurikulum, IHT sebagai tempat para guru untuk mendalami bahasa Inggris, dan memberikan kesempatan para guru untuk melanjutkan ke jenjang yang lebih tinggi

2. Pelaksanaan Pengembangan Kurikulum Program Unggulan

Implementasi kurikulum program unggulan ditandai dengan proses pembelajaran dirancang betul untuk memberikan pengalaman yang melibatkan proses mental dan fisik melalui interaksi antar peserta didik dengan guru, untuk mencapai itu maka dipilih suatu pendekatan student centre, learning cooperative, super learning DD/CT, CTL, Quantum learning dan PAKEM tentunya. Disamping itu, mengingat peserta didik dalam kelas akselerasi memiliki kecerdasan yang luar biasa, maka untuk mempercepat belajar setiap individu harus dikembangkan model layanan belajar yang memungkinkan siswa belajar terus menerus berkesinambungan, sehingga guru harus mempersiapkan dan mendesain pembelajaran yang fleksibel dan menyenangkan dengan rencana pembelajaran yang efektif dan efisien. Salah satunya guru harus mempersiapkan modul pembelajaran. Pelaksanaan kurikulum program unggulan juga berusaha meningkatkan mutu pendidikan melalui guru sebagai tenaga pendidikan, yang diimplementasikan dalam beberapa kegiatan diantaranya workshop, pelatihan IHT yakni untuk meningkatkan kemampuan bahasa Inggris para guru dengan bekerja sama dengan PTN untuk meningkatkan kualitas tenaga pendidik, pihak madrasah juga melakukan kerjasama dengan pihak luar.

${ }^{31}$ Hamalik, Manajemen Pengembangan, 152.

32 Hamalik, Manajemen Pengembangan, 152.

Jurnal Pendidikan Agama Islam

Volume 4 Nomor 1 Mei 2016

ISSN(p) 2089-1946\& ISSN(e) 2527-4511

Hal. 108 - 115 
Dosen-dosen dari PTN ternama kerap dihadirkan demi meningkatkan kompetensi guru dalam melakukan kegiatan pembelajaran.

Orang mungkin berfikir bahwa kurikulum yang dirumuskan oleh guru untuk menggunakan dalam kelas mereka sendiri akan merupakan hal yang paling mudah pada pelaksanaan. Guru akan mengerti dengan jelastujuan dan telah memikirkan dengan baik kesempatan belajar untukmencapainya. Akan tetapi hal itu tidaklah sesederhana itu, guru akan mengalami banyak hambatan dalam pelaksanaannya di kelas. ${ }^{33}$

Pembelajaran di dalam kelas merupakan tempat untukmelaksanakan dan menguji kurikulum. Dalam kegiatan pembelajaran semua konsep, prinsip, nilai, pengetahuan, metode, alat, dan kemampuan guru diuji dalam bentuk perbuatan, yang akan mewujudkan bentuk kurikulum yang nyata (actual curriculum-curriculum in action). Perwujudan konsep, prinsip, dan aspek-aspek kurikulum tersebut seluruhnya terletak pada kemampuan guru sebagai implementator kurikulum.

Oleh karena itu, gurulah kunci pemegang pelaksana dan keberhasilan kurikulum, gurulah yang bertindak sebagai perencana, pelaksana, penilai, dan pengembang kurikulum yang sebenarnya. Suatu kurikulum diharapkan memberi landasan, isi, dan menjadi pedoman bagi pengembangan kemampuan siswa secara optimal sesuai dengan tuntutan dan kebutuhan siswa, orang tua, dan masyarakat (stakeholders).

Pembinaan kurikulum pada dasarnya adalah usaha pelaksanaan kurikulum di sekolah, sedangkan pelaksanaan kurikulum itu sendiri direalisasikan dalam proses belajar-mengajar sesuai dengan prinsip-prinsip dan tuntutan kurikulum yang telah dikembangkan sebelumnya bagi suatu jenjang pendidikan atau sekolah-sekolah tertentu.

Pokok-pokok kegiatan tersebut dapat dikelompokkan menjadi 9 pokok kegiatan saja, yaitu: (1) kegiatan yang berhubungan dengan tugas kepala sekolah, (2) kegiatan yang berhubungan dengan tugas guru, (3) kegiatan yang berhubungan dengan murid, (4) kegiatan yang berhubungan dengan proses belajar-mengajar, (5) kegiatan-kegiatan ekstra kurikuler, (6)kegiatan pelaksanaan evaluasi belajar, (7) kegiatan pelaksanaan pengaturan alat perlengkapan sekolah, (8) kegiatan dalam bimbingan dan penyuluhan, (9) kegiatan yang berkenaan dengan usaha peningkatan mutu profesional guru. ${ }^{34}$

Guru bertanggung jawab melaksanakan PBM di kelas melalui proses belajar-mengajar secara efektif. Karena itu kemampuan profesional guru turut menentukan apakah suatu kurikulum dapat beroperasi secara efisien dan efektif. Tingkat efisiensi itu ditentukan oleh derajat kelancaran yang ditempuh, sedangkan tingkat efektivitasnya ditandai oleh derajat keberhasilannya, yakni dalam bentuk perubahan perilaku para siswa, yang kita kenal dengan sebutan prestasi belajar.

33John D. Mc. Neil, Kurikulum (sebuah pengantar komprehensif), (Jakarta; Wira Sari, 1988), 192. ${ }^{34}$ Hamalik, Manajemen Pengembangan, 169 
Pelaksanaan kurikulum yang berdaya guna dan berhasil guna sangat tergantung pada kemampuan guru itu sendiri, atau dengan kata lain di kalangan guru mungkin terdapat kesulitan dalam prosedur pelaksanaannya dan mungkin juga ada yang merasa mendapat hambatan berkenaan dengan kelemahan dalam dimensi tertentu pada kemampuan profesionalnya. Dalam situasi ini, maka sudah tentu guru-guru bersangkutan membutuhkan bantuan, bimbingan arahan, dorongan kerja, bahkan mungkin nasihat dan petunjuk yang berguna baginya dalam upaya pelaksanaan kurikulum tersebut. ${ }^{35}$

Berkaitan dengan tanggung jawab guru dalam pelaksanaan prosesbelajar mengajar, menyediakan ruangan bahasa (IHT) bagi guru, dalam rangka membantu para guru mengasa kemampuan bahasa inggris. Sedangkan bagi siswa, melaksanakan reading habit setiap hari senin sampai hari Jum'at yang dilaksanakan selama 10 menit setelah masuk baik itu reading maupun listening. Selain itu, untuk mata pelajaran MIPA menggunakan bilingual dalam proses belajar mengajar.

Miller dan Saller menyatakan:"in some cases, implementation hasbeen identified with instruction...." Demikian pula Saylor, dkk mengemukakan bahwa: "instruction is thus the implementation of thecurriculum plan, usually, but not necessarily, involving teaching in thesense of student teacher interaction in an educational setting".

Pengertian tersebut memberikan pemahaman bahwa kurikulum dalam dimensi kegiatan adalah sebagai manifestasi dari upaya untuk mewujudkan kurikulum yang masih bersifat dokumen tertulis menjadi actual dalam serangkaian aktivitas pembelajaran.

Dalam pelaksanaan kurikulum mengacu pada silabus dan RPP yang telah dirancang awal ajaran melalu workshop. Selain itu juga melaksanakan program ujian sertifikat cambridge bagi siswa sekolah lain yang ingin mengikuti program ini.

Menurut Hasan, sebagaimana dikutip Rusman, ${ }^{36}$ ada beberapa faktor yang memengaruhi implementasi kurikulum, yaitu "karakteristik kurikulum, strategi implementasi, karakteristik penilaian, pengetahuan guru tentang kurikulum, sikap terhadap kurikulum, dan keterampilan mengarahkan."

3. Evaluasi Pengembangan Kurikulum Program Unggulan

Evaluasi kurikulum program unggulan dilaksanakan dalam bentuk evaluasi formatif dan evaluasi sumatif. Semua evaluasi tersebut digunakan untuk mengukur keberhasilan peserta didik dan digunakan sebagai bagi peserta didik.

Dalam pola pemikiran evaluasi kurikulum dapat kita pahamipentingnya evaluasi kurikulum itu dalam berbagai tingkat sebagai berikut:

\footnotetext{
${ }^{35}$ Hamalik, Manajemen Pengembangan, 170.

${ }^{36}$ Rusman, Manajemen Kurikulum, 74.

Jurnal Pendidikan Agama Islam

Volume 4 Nomor 1 Mei 2016

ISSN(p) 2089-1946\& ISSN(e) 2527-4511

Hal. 110 - 115
} 
a. Guru bidang studi

Guru bidang studi berkepentingan menilai para siswanya untuk melihatsejauh mana proses belajar mengajar yang telah dilaksanakannya ituberhasil apa kurang berhasil. Selanjutnya dia dapat melihat keefektifan sistem instruksional yang telah dikembangkannya. Informasi yang diperoleh menjadi umpan balik terhadap pelaksanaan GBPP bidang studi tersebut dan memberikan informasi untuk membuat keputusaninstruksional serta pembinaan program sekolah secara menyeluruh.

b. Kepala sekolah

Kepala sekolah berkepentingan karena terkait dengan tugasnya sebagai administrator dan supervisor di sekolahnya, bertanggung jawab melaksanakan evaluasi terhadap program sekolah dalam rangkapelaksanaan kurikulum sekolah secara menyeluruh. Dia harus mengetahui dengan tepat dan cermat tentang pelaksanaan dan keberhasilan pelaksanaan kurikulum yang mencakup semua bidang studi atau mata pelajaran, apakah berjalan lancar dan apakah berhasil atau kurang berhasil; dan jika kurang berhasil, selanjutnya dia bersama guru-guru memikirkan kembali untuk melakukan berbagai upaya perbaikan. ${ }^{37}$

Menurut S. Hamid Hasan,38 evaluasi kurikulum dan evaluasi pendidikan memiliki karakteristik yang tak terpisahkan. Karakteristik itu adalah lahirnya berbagai definisi untuk suatu istilah teknis yang sama. Demikian pula dengan evaluasi yang diartikan oleh berbagai pihak dengan berbagai pengertian. Hal tersebut disebabkan filosofi keilmuan yang dianut seseorang berpengaruh terhadap metodologi evaluasi, tujuan evaluasi, danpada gilirannya terhadap pengertian evaluasi.

Menurut Tyler, evaluasi berfokus pada upaya untuk menentukan tingkat perubahan yang terjadi pada hasil belajar. Hasil belajar tersebut biasanya diukur dengan tes. Tujuan evaluasi menurut Tyler, yaitu untuk menentukan tingkat perubahan yang terjadi, baik secara statistik, maupun secara edukatif.39

Evaluasi adalah perbuatan pertimbangan berdasarkan seperangkat kriteria yang disepakati dan dapat dipertanggungjawabkan. Dalam hal ini ada tiga faktor utama, yaitu:(1) pertimbangan; (2) deskripsi objek penilaian; dan (3)kriteria yang dapat dipertanggungjawabkan. Pertimbangan (judgement) adalah pangkal dalam membuat suatu keputusan. Membuat keputusan berarti menentukan derajat tertentu yang berkenaan dengan hasil evaluasi itu. Pertimbangan membutuhkan informasi yang akurat dan relevan serta dapat dipercaya. Jika suatu keputusan dibuat tanpa suatu

\footnotetext{
370emar Hamalik, Evaluasi Kurikulum, (Bandung: PT Remaja Rosdakarya, 1990), 4. ${ }^{38}$ S.Hamid Hasan, Evaluasi Kurikulum(Bandung: PT Remaja Rosdakarya, 2008), 32.

${ }^{39}$ Hasan, Evaluasi Kurikulum, 32
} 
proses pertimbangan yang mantap, hal itu dapat mengakibatkan lemahnya atau kurang mantapnya keputusan.

Deskripsi objek penilaian adalah perubahan perilaku sebagai produk suatu system. Sudah barang tentu perilaku itu dijelaskan, dirinci, dan dispesifikasikan sehingga dapat diamati dan diukur. Kriteria yang dapat dipertanggungjawabkan adalah ukuran-ukuran yang akan digunakan dalam menilai suatu kurikulum.

Kriteria penilaian harus relevan dengan kriteria keberhasilan, sedangkan kriteria keberhasilan harus dilihat dalam hubungannya dengan sasaran program. Kriteria evaluasi harus memenuhi persyaratan diantaranya: (1)relevan dengan kerangka rujukan dan tujuan evaluasiprogram kurikulum, (2)diterapkan pada data deskriptif yang relevan dan menyangkut program/kurikulum.

Menurut Nana Syaodih peranan evaluasi kebijaksanaan dalam kurikulum khususnya pendidikan umumnya minimal berkenaan dengan tiga hal, yaitu evaluasi sebagai moral judgement, evaluasi dan penentuan keputusan, evaluasi dan consensus nilai. ${ }^{40}$

Berdasarkan beberapa pendapat di atas, dapat disimpulkan bahwa evaluasi lebih bersifat komprehensif yang di dalamnya yang meliputi pengukuran. Di samping itu, evaluasi pada hakikatnya merupakan suatu proses membuat keputusan tentang nilai suatu objek. Keputusan evaluasi (value judgment) tidak hanya didasarkan pada hasil pengukuran (quantiative description), dapat pula didasarkan kepada hasil pengamatan (qualitative description). baik yang didasarkan kepada hasil pengukuran (measurement) maupun bukan pengukuran (non-measurement) pada akhirnya menghasilkan keputusan nilai tentang suatu program/kurikulum yang dievaluasi. ${ }^{41}$ Dalam melaksanakan evaluasi/penilaian, lebih banyak mengacu pada kurikulum nasional, dengan menambahkan penilaian dari Cambridge. Adapun penilaian oleh pendidik itu (guru), ada penilaian ulangan harian, ada penilaian ulangan tengah semester dan ada penilaian ulangan akhir semester, baik semester ganjil maupun semester genap. Mulai UTS, UAS, UKK oleh pendidik dalam hal ini guru dikoordinator oleh satuan pendidikan. Kemudian, ada penilaian oleh sekolah yang disebut ujian sekolah yang diselenggarakan pada kelas tiga, dan ada penilaian dari pemerintah, yaitu ujian nasional.

Penilaian adalah penilaian yang mengikuti kurikulum nasional. Agar bisa terukur oleh kurikulum internasional (Cambridge) yang dirujuk menjadi kurikulum KTSP plus, yang penilaiannya dilaksanakan setiap ulangan tengah semester atau kenaikan kelas, menyiapkan juga kurikulum untuk penilaian dalam bentuk bahasa Inggris, tapi hasilnya tidak dimasukkan kedalam rapor, hanya dilampirkan dalam bentuk transkrip. Kemudian juga mengadakan sertifikasi internasional yang diselenggarakan

\footnotetext{
${ }^{40}$ Sukmadinata, Pengembangan Kurikulum, 179-180.

${ }^{41}$ Rusman, Manajemen Kurikulum, 93-94.

Jurnal Pendidikan Agama Islam

Volume 4 Nomor 1Mei 2016

ISSN(p) 2089-1946\& ISSN(e) 2527-4511

Hal. 112 - 115
} 
dua kali dalam setahun, yang kriteria soal dan penilaianya dari Cambridge. Jadi, penilaian yang ada diantaranya penilaian dari guru, satuan pendidikan, oleh pemerintah, dan oleh OECD. Yakni Cambridge Internasional. Selain itu, juga melakukan penilaian secara struktur yang disebut UHT (ujian harian terstruktur) yang dilaksanakan secara setiap hari Sabtu, sebagai upaya untuk memperdalam pemahaman materi.

\section{G. Kesimpulan}

Adapun perencanaan kurikulum yang dilakukan dalam mencapai tujuan kurikulum adalah kurikulum yang digunakan adalah kurikulum SNP plus X adaptif Cambridge, sehingga siswanya dapat mengikuti ujian Cambridge, sukses ujian nasional dan sukses OSN (olimpiade sains naional) dengan membedah SKL mulai dari kelas X. Dalam pelaksanaan kurikulum mengacu pada silabus dan RPP yang telah dirancang awal ajaran melalui workshop. Selainitu juga melaksanakan program ujian sertifikat cambridge bagi siswa sekolah lain yang ingin mengikuti program ini. Evaluasi kurikulum program unggulan dilaksanakan dalam bentuk evaluasi formatif dan evaluasi sumatif. Semua evaluasi tersebut digunakan untuk mengukur keberhasilan peserta didik dan digunakan sebagai bagi peserta didik.

\section{H. Referensi}

Arief, Rachman, Tim Konsultan Proyek Peningkatan Mutu SMU Paket- 2, Panduan Pelatihan Untuk Pengembangan Sekolah. Jakarta: Departemen Pendidikan Nasional, 2000.

BSNP, Panduan Penyusunan Kurikulum Tingkat Satuan Pendidikan Jenjang Pendidikan Dasar dan Menengah. Jakarta: Badan Standar Nasional Pendidikan, 2006.

Crawford, M., N. Bennet, C. Riches, Managingange in Education: Individual and Organization Perspektif. London: Paul Chapman Publishing Co, 1992.

Dikmenum, Peningkatan Mutu Pendidikan Berbasis Sekolah: Suatu Konsepsi Otonomi Sekolah. Jakarta: Depdikbud, 1999.

Hamalik, Oemar, Dasar-dasar Pengembangan Kurikulum. Jakarta: Remaja Rosdakarya, 2006.

Hamalik, Oemar, Evaluasi Kurikulum.Bandung: PT Remaja Rosdakarya, 1990.

Hamalik, Oemar, Manajemen Pengembangan Kurikulum.Jakarta: Remaja Rosda Karya, 2008.

Harsono, Pengantar Problem-Based Learning. Yogyakarta: Medika, 2005.

Hasan, S.Hamid, Evaluasi Kurikulum.Bandung: PT Remaja Rosdakarya, 2008.

Lawrence, Grayson, On a Methodology for Curriculum Design. Engineering Education, 1978. 
Manjta, W., Manajemen Pendidikan dan Supervisi Pengajaran. Malang: Wineka Media, 2002.

Marty, Nurdin, Implementasi Dasar-dasar Manajemen Sekolah Dalam Era Otonomi Daerah. Yogyakarta: Arruz Media, 2008.

Mohrman, Susan Albers, et.al., School Based Management: Organizing for High Performance. San Francisco: Mc Gill Publishing, 1994.

Muhaimin, Manajemen Penjaminan Mutu di Universitas Islam Negeri Malang. Malang: UIN, 2005.

Muhaimin, Pengembangan Kurikulum Pendidikan Agama Islam. Jakarta: Raja Grafindo Persada, 2005.

Muslich, Masnur, KTSP Pembelajaran Berbasis Kompetensi dan Kontekstual. Jakarta: Bumi Aksara, 2007.

Nasution, Asas-asas Kurikulum. Jakarta: Bumi Aksara, 2003.

Neil, John D. Mc., Kurikulum (sebuah pengantar komprehensif). Jakarta; Wira Sari, 1988.

Nizar, Samsul, Filsafat Pendidikan Islam: Pendekatan Historis, Teoritis dan Praktis. Jakarta: Ciputat Pers, 2002.

Prawiradilaga, Dewi Salma, Mozaik Tekonologi Pendidikan. Jakarta: Kencana, 2004.

Purwanto, Ngalim, Administrasi dan Supervisi Pendidikan.Bandung: Penerbit PT. Remaja Rosdakarya, 1998.

Ramayulis, Ilmu Pendidikan Islam. Jakarta: Kalam Mulia, 2006.

Rosyadi, Khoiron, Pendidikan Profetik. Yogyakarta: Pustaka Pelajar, 2004.

Rusman, Manajemen Kurikulum. Jakarta: Rajawali Pers, 2009.

Semiawan, Conny R., Soedijarto, Mencari Strategi Pengembangan Pendidikan Nasional Menjelang Abad XXI.Jakarta: PT. Grasindo, 1991.

Siagian, Sondang P., Fungsi-Fungsi Manajerial.Jakarta: Penerbit Bumi Aksara, 1992.

Sudrajad, H., Manajemen Peningkatan Mutu Berbasis Sekolah.Bandung: CV. Cipta Cekas Grafika, 2005.

Sukmadinata, Nana Syaodih, Pengembangan Kurikulum, Praktek dan Teori.Bandung: Remaja Rosdakarya, 2007.

Universitas Gajah Mada, Sistem Penjaminan Mutu Perguruan Tinggi. Yogyakarta: UGM, 2004.

Victorian's Departement of Education, How Good is Our School: School Performance for School Councillors. Australia, Melbourne, 1998. 
Manajemen Pengembangan Kurikulum

Widjaya, AW., Perencanaan sebagai Fungsi Manajemen.Jakarta. PT Bina Aksara, 1987.

Jurnal Pendidikan Agama Islam

Volume 4 Nomor 1 Mei 2016 ISSN(p) 2089-1946\& ISSN(e) 2527-4511 Hal. 115 - 115 